the series) and further information can be obtained from the Administrative Secretary, British PsychoAnalytical Society, 63 Now Cavendish Street, London, W.1.

\section{Advanced Courses in Technology}

A most useful booklet for all in the London area who are interested in advanced technological studies has been prepared by the London and Home Counties Regional Advisory Council for Higher Technological Education. The booklet describes all the courses which are available and which are not announced in college calendars or prospectuses. They are, as a rule, part-time (usually evening) courses ; but fulltime courses which are specially arranged and are not of longer than three months duration are also included. The courses range from silicone polymer technology to the organization of civil engineering contracts and from advanced archive administration to the industrial applications of servo-mechanisms. The booklet is clearly indexed and gives particulars of the venues of courses, the lecturers, and the approximate fees. Copies can be obtained from the Secretary, Tavistock House South, Tavistock Square, London, W.C.1.

\section{The Night Sky in March}

New moon occurs on March 12d. 13h. 36m., U.T., and full moon on March 26d. 13h. 11m. The following conjunctions with the Moon take place : March 3d. 15h., Saturn $3^{\circ}$ N.; March 1ld. 0h., Mercury $7^{\circ}$ S.; March 16d. 04h., Venus $1^{\circ} \mathrm{S}$; March 23d. 15h., Jupiter $6^{\circ}$ N.; March 30d. 23h., Saturn $3^{\circ} \mathrm{N}$. Mercury is too close to the Sun during the month for observation. Venus sets at $21 \mathrm{~h}$. $30 \mathrm{~m}$., 22h. $15 \mathrm{~m}$. and 23h. on March 1, 15 and 31, respectively, its stellar magnitude varying between $-3 \cdot 6$ and -3.9 and the visible portion of its illuminated disk decreasing from 0.701 to 0.575 ; during the month its distance from the Farth decreases from 96 to 75 million miles. Mars rises at $3 \mathrm{~h} .50 \mathrm{~m}$., $3 \mathrm{~h} .25 \mathrm{~m}$. and $3 \mathrm{~h}$. on March 1, 15 and 31, respectively, and lies rather low in the constellation Sagittarius, in which it has an eastward movement and is a little south of $\alpha$ Sagittarii on March 23; its stellar magnitude varies between $1 \cdot 2$ and $0 \cdot 8$, and its distance from the Earth between 146 and 122 million miles during the month. Jupiter is visible throughout the night, setting at $6 \mathrm{~h} .25 \mathrm{~m}$., $5 \mathrm{~h} .30 \mathrm{~m}$. and $4 \mathrm{~h} .25 \mathrm{~m}$. at the beginning, middle and end of the month, respectively, and has a westward movement in Leo; its stellar magnitude varies between $-2 \cdot 0$ and $-1 \cdot 9$, the small decrease in brightness being due to its distance from the Earth increasing from 410 to 435 million miles. Saturn rises at $1 \mathrm{~h} .10 \mathrm{~m} ., 0 \mathrm{~h} .10 \mathrm{~m}$. and $23 \mathrm{~h} .10 \mathrm{~m}$. on March 1, 15 and 31, respectively, and lies rather low for good observation in Scorpius, a little north of $\beta$ Scorpii ; its brightness increases by $0.2 \mathrm{mag}$. owing to its distance from the Earth decreasing from 909 to 867 million miles during the month. Occultations of stars brighter than magnitude 6 are as follows, observations being made at Greenwich : March $18 \mathrm{~d}$. 19h. 36.1m., ¿ Tau. $(D)$; March 22d. 23h. 45.9m., $x$ Cnc. $(D), D$ referring to disappearance. The Sun enters the first point of Aries on March 20d. 15h. $21 \mathrm{~lm}$.

\section{Announcements}

SrR EDWARD APPLETon, principal and vicechancellor of the University of Edinburgh, will deliver the Reith Lectures for 1956. The lectures,
"Science and the Nation", will be broadcast on the B.B.C. Home Service in the autumn.

THE Countess of Albemarle and the Right Hon. Lord Justice Morris have been appointed additional members of the University Grants Committee on matters relating to academic salaries only.

Prof. J. Piveteau, professor of palæontology in the University of Paris, has been elected a member of the Geology Section of the Paris Academy of Sciences in succession to the late Prof. A. Michel-Lévy.

THE Ninth International Botanical Congress will be held in Montreal during the summer of 1959. Preparations for the Congress have been initiated, but the exact date and officers of the Congress will be announced later. For the present all communications should be addressed to the Secretary of the Executive, Dr. A. J. Skolko, Botany and Plant Pathology Division, Science Service Building, Carling Avenue, Ottawa, Ontario.

A MEETING of the Malacological Society of London will be held on March 14 at 6 p.m. in the. rooms of the Linnean Society, Burlington House, London. W.I, when "Pelagic Mollusca: Swimmers and Drifters" will be considered. Four papers will be read, and then the meeting will be thrown open for discussion. Further information can be obtained from the honorary secretary of the Society, G. I. Crawford, 18 East Drive, Carshalton, Surrey.

A short course on the elements of radiological protection (that is, personal safeguards against radiation) will be held at the Isotope School, Atomic Energy Research Establishment, Harwell, during April 9-13. The course will consist of Jectures and practical work and is primarily intended for industrial users of radioactive isotopes. Application forms and further details can be obtained from the Isotope School and, as the number of places is limited, these should be returned before March 9 .

THE Industrial Committee of the Scientific Film Association is organizing a course on "First Steps in Industrial Film Making", to be held during March 5-8 at "Wansfell", Theydon Bois, Essex, a residential college of the Essex Local Education Authority. The course is not for those engaged professionally in the making of films but rather for those in industry who may have occasion to make a film $(16 \mathrm{~mm}$. silent or sound) in such fields as work study, the recording of processes or installations, or the simplest forms of illustration for instructional purposes. The course is residential, and the fee is 8 guineas. Further information can be obtained from the General Secretary, Scientific Film Association, 164 Shaftesbury Avenue, London, W.C.2.

THe Ministry of Agriculture, Fisheries and Food is offering the following scholarships for rural workers or the children of rural workers, of seventeen years of age or more : twenty senior scholarships, tenable at universities or colleges, for a degree or diploma in an agricultural subject or veterinary science; thirty junior scholarships and six extensions for existing holders, tenable at farm institutes, for one-year courses. Selection is by interview only. Further information and application forms (to be completed by February 29) can be obtained from the Secretary, Ministry of Agriculture, Fisheries and Food (Room 290), Great Westminster House, Horseferry Road, London, S.W.I, or from education offices of County Councils. 